\title{
Identifying Gap of Knowledge about Thermal Comfort in Naturally Ventilated Wards in Hot-humid Settings
}

\author{
Stavroula K Koutroumpi* \\ Department of Architecture, University of Cambridge, UK
}

*Corresponding author: Stavroula K Koutroumpi, Department of Architecture, University of Cambridge, 1 Scroope Terrace, Cambridge CB2 1PX, UK.

Received Date: June 16, 2020

Published Date: July 28, 2020

\begin{abstract}
This short review, drawing on sixteen studies that combined environmental and subjective measurements in hospital spaces, aims to highlight gaps in knowledge about thermal comfort in naturally ventilated wards in hot-humid settings. Although thermal comfort in naturally ventilated wards has been a significantly overlooked topic, wind-driven ventilation remains the primary mechanism for cooling and infection control in many hospital buildings with limited resources across the equatorial zone of the Global South. Identified evidentiary gaps include the lack of thermal comfort indexes with applicability for hospitalized patients in naturally ventilated wards with hot and humid conditions. To date across the equatorial zone, thermal comfort surveys of environmental and behavioral performances have not been applied in naturally ventilated inpatient facilities. At the same time, the interoperability of existing findings is limited by the lack of representative samples and comparable thermal acclimatization levels. In particular, the improvement of knowledge as regards existing thermal conditions and occupant adaptive behaviors can assist in the mitigation of overheating in hospital spaces that has become even more urgent in naturally ventilated wards across the equatorial zone, which are repurposed for the treatment of COVID-19 patients as the current pandemic evolves.
\end{abstract}

Keywords: Thermal comfort; Hospital; Inpatient ward; Natural ventilation; Hot-humid; Review

Abbreviations: Predicted Mean Vote: P.M.V; American Society of Heating Refrigerating and Air-Conditioning Engineers: ASHRAE; American Institute of Architects: AIA; Corona Virus Disease 2019: COVID-19; Actual Mean Vote: A.M.V

\section{Introduction}

Thermal comfort can be broadly defined as a physiological and psychological condition of content with the thermal conditions of the ambient environment as these are defined by the combined effect of temperature, humidity, and airflow [1]. Beyond the determination of the thermally acceptable thermal zones, research about thermal comfort in hospitals has been driven by the investigation about the influence of physiological thermoregulation, activity levels and clothing insulation, which are crucial modifiers of thermal comfort and significantly differ among health-workers, patients and visitors due to their different roles in the strictly controlled hospital environment, on thermal comfort votes, acceptable thermal conditions and the applicability of P.M.V. index
[2]. Although mechanical air-conditioning of inpatients facilities remains the primary recommendation by regulatory institutions with international influence, such as $[3,4]$, acceptable temperature and airflow rate in naturally ventilated wards stand between $8{ }^{\circ} \mathrm{C}$ and $28{ }^{\circ} \mathrm{C}$ and minimum $6 \mathrm{ACH}$, respectively [5]. The Category I of the EN15251 [6] adaptive thermal comfort standard has been presented as the sole suitable overheating assessment tool for naturally ventilated hospital spaces, including inpatient facilities. However, being applicable only in the 8.00-25.00 ${ }^{\circ} \mathrm{C}$ range of outdoor temperatures (running mean) has limited use for hospital wards across the equatorial zone. Furthermore, the ASHRAE 55 standard [7], which was revised according to 21,000 fieldwork data 
from 160 non-domestic buildings (hospitals were excluded) in four different continents including the equatorial zone, is suitable for the assessment of thermal comfort only among healthy adults in naturally ventilated spaces.

According to the sole data available regarding the energy consumption for hospital cooling, the most impoverished countries with the weakest health systems, which are found in highest concentration in Africa, have the lowest levels of energy consumption for hospital cooling [8]. Therefore, it is likely that as the current COVID-19 pandemic evolves across the Global South, naturally ventilated clinical spaces will be repurposed for the treatment of COVID-19 cases. In this article, a critical review of thermal comfort studies in hospital spaces is presented, with the aim to highlight gaps in knowledge about thermal comfort in naturally ventilated wards in hot-humid settings. Using the keywords of thermal comfort, overheating and hospital, systematic database searching in peer-reviewed articles being published from 1970 to 2020 was conducted in ScienceDirect, PubMed and MEDLINE. Only sixteen studies were selected for this review. These were the only studies that combined on-site environmental and subjective measurements in occupied hospital spaces (Table 1). This review addresses the following key question: Which are the research gaps as regards thermal comfort in naturally ventilated hospital wards across the equatorial zone of the Global South?

Table 1: Overview of evidence collected during thermal comfort surveys, which combined objective and subjective measurements, in hospital spaces across the temperature and equatorial zones.

\begin{tabular}{|c|c|c|c|c|c|c|c|c|c|}
\hline Authors & $\begin{array}{l}\text { Location } \\
\text { (Climate }{ }^{1} \text { ) } \\
\text { Season) }\end{array}$ & $\begin{array}{l}\text { Cooling, } \\
\text { Heating } \\
\text { and Ven- } \\
\text { tilization } \\
\text { Systems } \\
\text { (Space } \\
\text { Function) }\end{array}$ & $\begin{array}{c}\text { Sample Size } \\
\text { (Occupant } \\
\text { Type) }\end{array}$ & $\begin{array}{l}\text { Indoor R.H. } \\
\text { (\%) (Space } \\
\text { Function) }\end{array}$ & $\begin{array}{c}\text { Long-term } \\
\text { (Space function) }\end{array}$ & $\begin{array}{l}\text { Spot. (Space function } \\
\text { season) }\end{array}$ & Neutral & $\begin{array}{l}\text { Comfortable } \\
\text { (A.P.D.=20\%) }\end{array}$ & $\begin{array}{c}\text { A.M.V. } \\
\text { (Space } \\
\text { function) } \\
\text { (Occu- } \\
\text { pant } \\
\text { type) }\end{array}$ \\
\hline $\begin{array}{c}\text { Yau \& } \\
\text { Chew } \\
{[23] \text { Yau }} \\
\& \text { Chew } \\
{[24]} \\
\end{array}$ & $\begin{array}{l}\text { Kuala Lum- } \\
\text { pur, Malaysia } \\
\text { (AF) (r. \& dr.) }\end{array}$ & $\begin{array}{l}\text { mechanical } \\
\text { (non-cli.) }\end{array}$ & 293 (st.) & & & & $\begin{array}{c}23.20-26.50^{\mathrm{b}+} \\
\text { (st.) }\end{array}$ & $23.70-27.70^{\mathrm{b}+}$ & \\
\hline $\begin{array}{c}\text { Aziz- } \\
\text { pour, et } \\
\text { al. [29] } \\
\text { Aziz- } \\
\text { pour, et } \\
\text { al. [27] } \\
\end{array}$ & $\begin{array}{l}\text { Cheras, Slon- } \\
\text { gor. Malaysia } \\
\text { (AF) }\end{array}$ & $\begin{array}{l}\text { mechanical } \\
\text { (non-cli.) }\end{array}$ & $\begin{array}{l}188 \text { (st. \& } \\
\text { vis.) }\end{array}$ & & & & $\begin{array}{l}23.40-26.80^{* b} \\
\text { (st.) (vis.) }\end{array}$ & $21.20-25.50^{c+}$ & $\begin{array}{l}0.75 \text { (st.) } \\
\text { (vis.) }\end{array}$ \\
\hline $\begin{array}{l}\text { Nema- } \\
\text { tchoua, } \\
\text { et al. } \\
(2017)^{4} \\
\end{array}$ & $\begin{array}{l}\text { Antsiranana, } \\
\text { Madagascar } \\
\text { (AW) (r. \& } \\
\text { dr.) }\end{array}$ & $\begin{array}{l}\text { natural } \\
\text { (non-cli.) }\end{array}$ & 198 (pat.) & & $\begin{array}{l}25.50-27.50^{+} \text {(dr.) } \\
24.50-25.00^{+} \text {(r.) }\end{array}$ & & $26.42^{\mathrm{b} *}$ (pat.) & $23.20-26.80^{\mathrm{b}+}$ & \\
\hline $\begin{array}{l}\text { Sattaya- } \\
\text { korn, et } \\
\text { al. [22] }\end{array}$ & $\begin{array}{c}\text { Bangkok, } \\
\text { Thailand } \\
\text { (AW) (r. \& } \\
\text { dr.) }\end{array}$ & $\begin{array}{l}\text { mechanical } \\
\text { (cli.) }\end{array}$ & $\begin{array}{l}146 \text { (st.) } \\
451 \text { (pat.) } \\
331 \text { (vis.) }\end{array}$ & $\begin{array}{l}43.00-85.00^{+} \\
\text {(w.r.) } 40.00- \\
93.00^{+} \text {(ex.r. } \\
\quad \text { \& n.s.) }\end{array}$ & $\begin{array}{c}20.00-29.30^{+} \\
\text {(w.r.) } 18.70- \\
29.30^{+} \text {(w.r.) } \\
18.70-29.60^{+} \text {(ex. } \\
\text { r. \& n.s.) }\end{array}$ & & $\begin{array}{c}21.80-27.90^{+\mathrm{b}} \\
\text { (pat.) } 22.00- \\
27.10^{+\mathrm{b}} \text { vis.) } \\
24.10-25.60^{+\mathrm{b}} \\
\text { (st.) }\end{array}$ & $\begin{array}{c}21.80-27.90^{\mathrm{b}+} \\
\text { (pat.) } 22.0- \\
27.0^{\mathrm{b}+} \text { (vis.) } \\
24.10-25.60^{\mathrm{b}+} \\
\text { (st.) }\end{array}$ & \\
\hline $\begin{array}{l}\text { Khalid, } \\
\text { et al. } \\
\text { [20] }\end{array}$ & $\begin{array}{l}\text { Kuala Lum- } \\
\text { pur, Malaysia } \\
\text { (AF) (r. \& dr.) }\end{array}$ & $\begin{array}{l}\text { mechanical } \\
\text { (in-pat.) }\end{array}$ & $\begin{array}{l}305 \text { (pat.) } \\
84 \text { (vis.) }\end{array}$ & & & $23.50^{\mathrm{b} *}$ (pat.r.) & & $\begin{array}{l}25.30^{\text {b+ }} \text { (pat.) } \\
25.50^{\text {b+ }} \text { (vis.) }\end{array}$ & $\begin{array}{l}-0.90 \\
\text { (pat.) } \\
-1.10 \\
\text { (vis.) } \\
\end{array}$ \\
\hline $\begin{array}{l}\text { Hwang, } \\
\text { et al. } \\
{[14]} \\
\end{array}$ & $\begin{array}{l}\text { Taiwan (Cfa) } \\
\text { (s. \& w.) }\end{array}$ & $\begin{array}{l}\text { mechanical } \\
\text { (in-pat.) }\end{array}$ & 927 (pat.) & & & & $\begin{array}{l}22.60-23.20^{\mathrm{b}} \\
\text { (w.) (pat.) }\end{array}$ & $\begin{array}{c}20.70-25.40^{\mathrm{b}} \\
\text { (w.) }\end{array}$ & \\
\hline $\begin{array}{c}\text { Khoda- } \\
\text { karami } \\
\quad \& \\
\text { Knight } \\
\text { [21] }\end{array}$ & $\begin{array}{l}\text { Iran (BWh, } \\
\text { BWk) }\end{array}$ & mechanical & $\begin{array}{c}79 \text { (pat.) } 41 \\
\text { (st.) }\end{array}$ & & & $\begin{array}{c}20.00-22.00^{c+} \text { (n.s.) } \\
22.00-24.00^{\mathrm{ct}} \text { (pat.r) } \\
26.00-28.00^{\mathrm{ct}} \text { (pat.r) }\end{array}$ & & $\begin{array}{c}19.00-26.00^{\mathrm{b}} \\
\text { (st.) } 22.50- \\
31.50^{\mathrm{b}} \text { (pat.r) }\end{array}$ & \\
\hline $\begin{array}{l}\text { Skoog } \\
{[26]^{2,3}}\end{array}$ & $\begin{array}{l}\text { Sweden (Cfb) } \\
\text { (s. \& w.) }\end{array}$ & $\begin{array}{l}\text { mixed (in- } \\
\text { pat.) }\end{array}$ & $\begin{array}{l}40 \text { (st.) } 35 \\
\text { (pat.) }\end{array}$ & & & $\begin{array}{c}21.50^{\mathrm{b} *} \text { (n.s.) (s.) } \\
21.40^{\mathrm{b} *} \text { (pat.r.) (s.) } \\
21.80^{\mathrm{b} *} \text { (st.) (w.) } \\
21.60^{*} \text { (pat.r.) (w.) }\end{array}$ & & & $\begin{array}{l}3.50 \text { (s.) } \\
\text { (st.) } 4.00 \\
\text { (s.) (pat.) } \\
3.70 \text { (w.) } \\
\text { (st.) } 3.90 \\
\text { (w.) (pat.) }\end{array}$ \\
\hline
\end{tabular}




\begin{tabular}{|c|c|c|c|c|c|c|c|c|c|}
\hline $\begin{array}{l}\text { Hashi- } \\
\text { guchi, et } \\
\text { al. [19] }\end{array}$ & $\begin{array}{l}\text { Fukuoka, } \\
\text { Japan (Cfa) } \\
\text { (w.) }\end{array}$ & $\begin{array}{l}\text { mechanical } \\
\text { (in-pat.) }\end{array}$ & $\begin{array}{l}36 \text { Ppat.) } 45 \\
\text { (st.) }\end{array}$ & $\begin{array}{c}29.0037 .00^{*} \\
\text { day (pat.r.) } \\
<30.00^{*} \text { day } \\
\text { (n.s.) }\end{array}$ & $23.00-25.00^{+ \text {day }}$ & $\begin{array}{c}22.1-27.60^{\mathrm{c}+} 23 / 3- \\
27.80^{\mathrm{b+}}\end{array}$ & & & \\
\hline $\begin{array}{c}\text { Verhey- } \\
\text { en, et al. } \\
\text { [17] }\end{array}$ & $\begin{array}{l}\text { Belgium } \\
\text { (Cfb) }\end{array}$ & $\begin{array}{l}\text { mechanical } \\
\text { (in-pat.) }\end{array}$ & 99 (pat.) & $59.4-69.2$ & & & & & \\
\hline $\begin{array}{l}\text { Pour- } \\
\text { shagh- } \\
\text { aghy, et } \\
\text { al. [16] }\end{array}$ & $\begin{array}{c}\text { Kermanshah, } \\
\text { Iran (Csa) (s. } \\
\text { \& w.) }\end{array}$ & $\begin{array}{l}\text { mechanical } \\
\text { (in-pat.) }\end{array}$ & $\begin{array}{l}403 \text { (sy. \& } \\
\text { pat.) }\end{array}$ & & & & & & \\
\hline $\begin{array}{l}\text { Wang, et } \\
\text { al. [18] }\end{array}$ & $\begin{array}{c}\text { Taiwan (Cfa) } \\
\text { (s.) }\end{array}$ & $\begin{array}{l}\text { mechanical } \\
\text { (cli. \& in- } \\
\text { pat.) }\end{array}$ & & & & & & $22.90-26.30$ & \\
\hline $\begin{array}{l}\text { De Giuli, } \\
\text { et al. } \\
\text { [11] }\end{array}$ & $\begin{array}{l}\text { Padova, Italy } \\
\text { (Cfa) }\end{array}$ & $\begin{array}{c}\text { mixed } \\
\text { mode (in- } \\
\text { pat.) }\end{array}$ & $\begin{array}{l}55 \text { (st.) } 35 \\
\text { (pat.) }\end{array}$ & $\begin{array}{c}24.00-33.00^{+} \\
\text {(ortho.) } \\
22.00-32.00^{+} \\
\text {(in.med.) }\end{array}$ & & $\begin{array}{c}26.80-28.30^{\mathrm{ct}} \text { (ortho.) } \\
26.30-28.20^{\mathrm{b+}} \text { (ortho.) } \\
24.00-25.10^{\mathrm{ct}} \text { (in.med.) } \\
23.90-26.00^{\mathrm{b+}}\end{array}$ & & & \\
\hline $\begin{array}{c}\text { Ferraro, } \\
\text { et al. } \\
\text { [13] }\end{array}$ & $\begin{array}{l}\text { Central Italy } \\
\text { (Csa) (au.) }\end{array}$ & $\begin{array}{l}\text { mechanical } \\
\text { (in-pat.) }\end{array}$ & $\begin{array}{l}19 \text { (st.) } 30 \\
\text { (pat.) }\end{array}$ & $\begin{array}{l}30.90- \\
45.70^{*}\end{array}$ & $20.90-24.30^{c+}$ & $20.90-24.30^{*}$ & & & $\begin{array}{c}0.61 \text { (st.) } \\
\text { (pat.) }\end{array}$ \\
\hline $\begin{array}{l}\text { Derks, } \\
\text { et al. } \\
\text { [12] }\end{array}$ & $\begin{array}{l}\text { Netherlands } \\
\text { (Cfb) (s. \& } \\
\text { au.) }\end{array}$ & $\begin{array}{c}\text { mechanical } \\
\text { (non-cli. \& } \\
\text { in-pat.) }\end{array}$ & 132 (st.) & $\begin{array}{c}54.10^{*}(\mathrm{~d} .) \\
\text { (s.) } \\
52.50^{*}(\mathrm{e} .) \\
\text { (s.) } \\
54.10^{*}(\mathrm{n} .) \\
\text { (s.) } \\
40.30^{*}(\mathrm{~d}) \\
\text { (a.) } \\
40.30^{*}(\mathrm{e} .) \\
\text { (a.) } \\
38.90^{*}(\mathrm{n} .) \\
\text { (a.) }\end{array}$ & $\begin{array}{c}20.00-25.00^{+} \\
23.50^{*}(\mathrm{~m} .)(\mathrm{s}) \\
23.60^{*} \text { (e.) (s.) } \\
23.20^{*} \text { (n.) (s.) } \\
22.40^{*} \text { (d.) (a.) } \\
22.50^{*} \text { (e.) (a.) } \\
22.30^{*} \text { (n.) (a.) }\end{array}$ & & $\begin{array}{l}20.20-23.30^{\mathrm{d}} \\
\text { (st.) }\end{array}$ & & \\
\hline $\begin{array}{c}\text { Alotaibi, } \\
\text { et al. } \\
\text { [25] }\end{array}$ & $\begin{array}{c}\text { Jeddah, } \\
\text { Saudi Arabia } \\
\text { (BWh)(s.) }\end{array}$ & $\begin{array}{l}\text { Mechanical } \\
\text { (in-pat.) }\end{array}$ & 120 (pat.) & $\begin{array}{l}41.51- \\
60.35^{*}\end{array}$ & $20.24-25.48^{c+}$ & & 25.59 & & $\begin{array}{c}0.32 \\
\text { (pat.) }\end{array}$ \\
\hline
\end{tabular}

aan empty cell indicates the lack of evidence.

${ }^{1}$ according to the Köppem-Getter climate classification system [15].

${ }^{2}$ reported evidence in this table is combined with the information about the same thermal comfort survey published by Skoog et al. [26] and by Fransson.et al. [26] ${ }^{3}$ windows were open during the survey in summer, whereas during winter they remained dosed.

${ }^{4}$ results from hospital spaces were grouped with results from shopping malls

Space function: cli=clinical space (s) only. Non-cli. = nonclinical space $(\mathrm{s})$ only. In-pat. =inpatient ward, pat. $r=$ patient room, w. $r .=$ waiting room, $n . s=$ nurse station, ex. r. = examination room, ortho. = orthopedics, inmed. = internal medicine, mat. = maternity, onc. = oncology, neu. = neurology, gas. = gastro-enterology, ab. sur. $=$ abdominal surgery, tho. sur. = thorovascular marshal.

Occupant type: st. $=$ Staff, pat. $=$ patient, vis. $=$ visitors

Key statistics: $=^{*}=$ mean, ${ }^{+}=\min -\max ,{ }^{\text {day }}=$ daily

Season: $\mathrm{s} .=$ summer, $\mathrm{w} .=$ wisnter, a. = autumn, $\mathrm{r}$. = Rainy, dr.= dry, au. = autumn

Time of the day/shift: $\mathrm{m} .=$ morning, $\mathrm{n} .=$ night, $\mathrm{e} .=$ evening

Environmental variables: ${ }^{b}=$ operative temperature, ${ }^{c}=$ air temperature, ${ }^{d}=$ effective temperature

\section{Discussion}

Mixed-methods thermal comfort field-surveys in hospital spaces in equatorial climates, which are limited to only five studies with three of them being conducted in Malaysia, failed to include the participation of hospitalized patients in naturally ventilated facilities (Table 1). Only Kushairi, et al. [9] performed a thermal comfort survey in an occupied open plan multibed ward in Kuala Lumpur, in Malaysia but without taking any environmental measurements, while [10] interviewed patients and took physical measurements in waiting across five hospitals in Antsiranana, in Madagascar. Low functional diversity of case-studies in both inpatient and outpatient facilities is evident among the thermal 
comfort surveys across the equatorial zone, whereas the casestudies across the temperate zone comprised in both surgical and medical wards with diverse specializations [11-18]. Across both the temperate and the equatorial zones, patients were the most studied type of hospital occupants, followed by hospital workers, whose responses were not differentiated according to their professional role in all the studies. At the same time, visitors have been included only in thermal comfort surveys in equatorial climates (Table 1). Female participants, especially among staff, prevailed in most of the samples across both the temperate and the equatorial zones $[12,18$ 21]. Whereas age distribution among patients covered a wide range of years $(10-80 \mathrm{yrs})[2,14,21,22]$, most of the interviewed hospital workers and visitors were in their twenties, thirties, and forties $[2,14,22,23,28]$. Patients tended to have the highest clothing insulation values especially among the studies that included the additional insulation of the bedcoverings (0.49-1.84clo) [11,20,21], whereas nurses were the most physically active (1.10-1.70 met) $[11,16,23]$.

Comparisons of acceptable thermal conditions between thermal comfort surveys in hospital spaces are limited by the lack of standardization in the reporting of the results as well as differences in the levels of thermal acclimatization among the participants, which were evident even between hospital spaces with similar functions, ventilation systems and outdoor climates (Table 1). These differences are indicated in the extensive range of outdoor temperatures and relative humidity levels were monitored during thermal comfort surveys in hospital spaces (Table 1). Recorded outdoor temperatures varied from 25.40 to $35^{\circ} \mathrm{C}$ in Kuala Lumpur, Malaysia [20,24], between $23.80-48.80{ }^{\circ} \mathrm{C}$ in Saudi Arabia [25], from -0.40 to $18.70{ }^{\circ} \mathrm{C}$ in the Netherlands [12], between 0 and $12{ }^{\circ} \mathrm{C}$ in Fukuoka, Japan [2], and above $29^{\circ} \mathrm{C}$ in Belgium [17], while recorded outdoor relative humidity levels stood from 42.30 to $89.30 \%$ in Fukuoka, Japan [2] and between 74.00 and $86 \%$ in Belgium [17]. Monitored indoor temperature ranges over both the rainy and dry seasons, were wider, varying from 20.00 to 29.30 ${ }^{\circ} \mathrm{C}$ in air-conditioned waiting rooms in Thailand [22], than those recorded in naturally ventilated waiting rooms in Madagascar that stood between 24.50 and $27.50{ }^{\circ} \mathrm{C}$ [10] (Table 1). Differentiations in the mean indoor temperatures between air-conditioned clinical spaces with different uses in Sweden and Japan were low (below $0.50 \mathrm{~K}$ ) $[2,26]$ (Table 1). De Giuli, et al. [11] found that wind-driven indoor airflows through openable windows had a weak impact (below $0.20 \mathrm{~K}$ ) on the in the fluctuations of the indoor mean temperature and relative humidity values in mixed-mode spaces in a hospital in Italy [11].

Reported thermal sensation votes in different air-conditioned hospital spaces in Malaysia indicated lower levels of thermal discomfort than in air-conditioned spaces in Sweden with patients and visitors in general wards [20] and staff and visitors in nonclinical spaces [27] feeling significantly cooler than patients in Sweden [26] (Table 1). Operative temperatures corresponding to "neutral" A.M.Vs. and to "slightly cool", "neutral" and "slightly warm" A.M.Vs. were in the $23.20-27.70{ }^{\circ} \mathrm{C}$ range in mechanically and naturally ventilated non-clinical spaces in Malaysia and Madagascar $[10,23,27]$. Among the surveyed air-conditioned hospital spaces across the temperate zone comfortable temperatures varied between 22.40 (in winter) and $22.60{ }^{\circ} \mathrm{C}$ (in summer) in an orthopaedical ward in Sweden [26] and from 20.30 and $23.30{ }^{\circ} \mathrm{C}$ in clinical and non-clinical spaces in the Netherlands [12], while in hospital spaces in Iran comfortable temperatures stood between 19.00 to $26.00{ }^{\circ} \mathrm{C}$ among staff, from 22.50 and $28.00{ }^{\circ} \mathrm{C}$ among patients covered with blankets and between 27.00 and $31.50{ }^{\circ} \mathrm{C}$ among patients without blankets [21]. The application of the PMV indexes according to the EN15121 (2008) and ASHRAE 55 (2013) standards resulted in the overestimation of thermal discomfort in the inpatient facilities in central Italy [13] and in Saudi Arabia [25] and the non-clinical spaces in Malaysia [27].

Limited evidence is provided in the published thermal comfort surveys in hospital spaces about the impact of seasonality, different spatial and temporal conditions, personal factors and the effect of humidity and airflow on thermal discomfort, especially among the studies across the equatorial climates. During summer unacceptability of the thermal conditions was higher than during winter in hospital spaces in the Netherlands [12]. The morning shift during winter and the evening shift during summer collected most of the discomfort votes in hospital spaces in Iran [16]. Low relative humidity levels adversely affected thermal comfort only during periods of high temperatures in an orthopaedical ward in Sweden [26]. Low airflow rates were linked with high levels of dissatisfaction with the indoor thermal conditions in inpatient and outpatient areas in a hospital in Taiwan [12]. Gender and age-based differences were found to be statistically significant only among the interviewed patients in the air-conditioned wards in central Italy, where female patients reported higher sensitivity to elevated temperatures and the coolest thermal sensations were expressed by patients older than sixty-five years [13].

\section{Conclusion}

The existing thermal comfort indexes of the EN15251 and the ASHRAE 55 standards cannot be applied for the assessment of thermal discomfort among patients being hospitalized in naturally ventilated wards with hot-humid conditions. There is no evidence about the thermal conditions and the perceived thermal comfort in operational naturally ventilated inpatient facilities across the equatorial zone, while the realized surveys in air-conditioned inpatient facilities across the equatorial zone have been applied to hospital spaces with limited functional diversity leaving an evidentiary gap as regards the thermal comfort-related challenges caused by the diverse operational requirements among spaces with diverse specialized functions. This lack of evidence becomes more important due to the limited interoperability of the findings from naturally ventilated wards across the temperate zone and 
from the air-conditioned wards across the equatorial zone. This lack of interoperability is primarily driven by the differences in the levels of thermal acclimatization among the hospital occupants and the small size samples. These participants' samples have been characterized by asymmetrical distributions of gender, age, clothing insulations and metabolic rates that limit their representativeness for hospital spaces across both the equatorial and the temperate zones. Furthermore, crucial aspects of thermal comfort in naturally ventilated spaces such as the effect of humidity and airflow and occupant-controlled window operation [10] have been overlooked from the existing thermal comfort surveys in mixed-mode and naturally ventilated spaces. Knowledge about occupant adaptive behaviors especially among those who are most vulnerable to thermal discomfort are fundamental for the efficient mitigation of overheating in hospitals [28]. Therefore, strategies for the mitigation of overheating in naturally ventilated wards across the equatorial zone that might be repurposed for the treatment of COVID-19 patients, although they are currently adversely affected by the significant lack of evidence, they can be greatly benefitted by studies that explore both environmental and behavioral performances in real-time in hot-humid clinical settings with limited resources [29].

\section{Acknowledgement}

This project was supervised by Professor Alan Short in the Department of Architecture at the University of Cambridge. Funding was provided by the Engineering and Physical Sciences Research Council, Welcome Trust and Smuts Memorial Trust.

\section{Conflict of Interest}

The author declares no financial interest and no conflict of interest.

\section{References}

1. Fanger PO (1970) Thermal Comfort, Analysis and Applications in Environmental Engineering. Copenhagen: Danish Technical Press.

2. Eijkelenboom AM, Bluyssen P (2019) Comfort and Health of Patients and Staff Related to the Physical Environment of Different Departments in Hospitals: a Literature review. Intelligent Buildings International, pp.1-19.

3. American Institute of Architects (AIA) (2001) Guidelines for Design and Construction of Hospital and Health Care facilities. Washington, DC American Institution of Architects.

4. American Society of Heating, Refrigerating and Air-Conditioning Engineers (ASHRAE) (2008) ASHRAE/ASHE STD 170-2008. Ventilation of Health Care Facilities. Atlanta, GA: American Society of Heating, Refrigerating, and Air-conditioning Engineers.

5. Department of Health (2013) In-patient Care Health Building Note 0401: Adult In-patient Facilities. London: Department of Health.

6. British Standards Institute (BSI) (2008) BS EN 15251:2007. Indoor Environmental Input Parameters for Design and Assessment of Energy Performance of Buildings Addressing Indoor Air Quality, Thermal Environment, Lighting and Acoustics. pdf] London: British Standards Institute.

7. American Society of Heating, Refrigerating and Air-Conditioning Engineers (ASHRAE) (2013) ASHRAE Standard 55-2013: Thermal
Environmental Conditions for Human Occupancy. Atlanta, GA: American Society of Heating, Refrigerating and Air-Conditioning Engineers.

8. Kigali Cooling Efficiency Program (2018) Global Climate Impact from Hospital Cooling. [pdf] Kigali: Kigali Cooling Efficiency Program.

9. Kushairi AAA, Mahyuddin N, Adnan E, Sulaiman R (2015) Perceptions on Thermal Comfort in General Wards for Malaysian Hospitals. Journal of Building Performance 6(1): 15-30.

10. Vellei M, Herrera M, Fosas D, Natarajan S (2017) The Influence of Relative Humidity on Adaptive Thermal Comfort. Building and Environment 124: 171-185.

11. De Giuli V, Zecchin R, Salmaso L, Corain L, De Carli M (2013) Measured and Perceived Indoor Environmental Quality: Padua Hospital Case Study. Building and Environment 59: 211-226.

12. Derks TH, Mishra AK, Loomans MGLC, Kort HSM (2018) Understanding Thermal Comfort Perception of Nurses in a Hospital Ward Work Environment. Building and Environment 140: 119-127.

13. Ferraro SD, Iavicoli S, Russo S, Molinaro V (2015) A Field Study on Thermal Comfort in an Italian Hospital Considering Differences in Gender and Age. Applied Ergonomics 50: 177-184.

14. Hwang RL, Lin TP, Cheng MJ, Chien JH (2007) Patient Thermal Comfort Requirement for Hospital Environments in Taiwan. Building and Environment 42(8): 2980-2987.

15. Koettek M, Grieser J, Beck C, Rudolf B, Rubel F (2006) World Map of Köppen- Geiger Climate Classification Updated. Meteorologische Zeitschrift 15: 259-263.

16. Pourshaghaghy A, Omidvari M (2012) Examination of Thermal Comfort in a Hospital Using PMV-PPD Model. Applied Ergonomics 43(6): 10891095.

17. Verheyen J, Theys N, Allonsius L, Descamps (2011) Thermal Comfort of Patients: Objective and Subjective Measurements in Patient Rooms of a Belgian Healthcare Facility. Building and Environment 46: 1195-1204.

18. Wang F, Lee M, Cheng T, Law Y (2012) Field Evaluation of Thermal Comfort and Indoor Environment Quality for a Hospital in a Hot and Humid Climate. HVAC and Research, pp. 671-680.

19. Hashiguchi N, Tochihara Y, Ohnaka T, Tsuchida C, Otsuki T (2004) Physiological and Subjective Responses in the Elderly When Using Floor Heating and Air Conditioning Systems. Journal of Physiological Anthropology and Applied Human Science 23(6): 205-213.

20. Khalid W, Zaki SA, Rijal HB, Yakub F (2019) Investigation of Comfort Temperature and Thermal Adaptation for Patients and Visitors in Malaysian Hospitals. Energy and Buildings 183(4): 84-99.

21. Khodakarami, Knight (2007) Thermal Comfort Requirements in Iranian Hospitals', Proceedings of Clima 2007 WellBeing Indoors, viewed 10 February 2016

22. Sattayakorn S, Ichinose M, Sasaki R (2017) Clarifying Thermal Comfort of Healthcare Occupants in Tropical Region: A Case of Indoor Environment in Thai Hospitals. Energy and Buildings 149(15): 45-57.

23. Yau YH, Chew BT (2009) Thermal Comfort Study of Hospital Workers in Malaysia. Indoor Air 19: 500-510.

24. Yau Y, Chew B (2014) Adaptive Thermal Comfort Model for Airconditioned Hospitals in Malaysia. Building Services Engineering Research and Technology 35(2): 117-138.

25. Alotaibi BS, Lo S, Southwood E, Coley D (2020) Evaluating the Suitability of Standard Thermal Comfort Approaches for Hospital Patients in Airconditioned Environments in Hot Climates. Building and Environment, vol. 169.

26. Skoog J, Fransson N, Jagemar L (2005) Thermal Environment in Swedish Hospitals Summer and Winter Measurements. Energy and Buildings 37(8): 872-877.

27. Azizpour, S Moghimi, CH Lim, S Mat, E Salleh, et al., (2013) Thermal Comfort Assessment of Large-scale Hospitals in Tropical Climates: A 
Case Study of University Kebangsaan Malaysia Medical Centre (UKMMC). Energy and Buildings 64: 317-322.

28. Carmichael C, Graham Bickler, Sari Kovats, David Pencheon, Virginia Murray et al., (2013) Overheating and Hospitals - What Do we Know? Journal of Hospital Administration 2(1): 1-8.
29. F Azizpour, S Moghimi, CH Lim, S Mat, E Salleh, et al., (2012) A Thermal Comfort Investigation of a Facility Department of a Hospital in Hot-Humid Climate: Correlation between Objective and Subjective Measurements. Indoor and Built Environment, pp.836-845. 